Article

\title{
Organizational Justice and Leadership Behavior Orientation as Predictors of Employees Job Satisfaction: Evidence from Croatia
}

\author{
Danica Bakotić *(D) and Ivana Bulog \\ Faculty of Economics, Business and Tourism, University of Split, 21000 Split, Croatia; ivana.bulog@efst.hr \\ * Correspondence: danicab@efst.hr
}

\begin{abstract}
The aim of this paper was to examine the role of organizational justice and leadership behavior orientation in predicting job satisfaction by focusing on three organizational justice dimensions (distributive, procedural, and interactional justice) and two leadership behavior orientations (task and relations-oriented behaviors). The empirical research was conducted in Croatia, during 2019. The research sample included 298 participants. Hierarchical regression analysis was conducted to empirically test proposed hypotheses focusing on organizational justice and leadership behavior orientation as predictors of employees' job satisfaction. Research results showed that interactional justice, distributive justice and relations-oriented leadership behavior have an almost equally powerful impact on job satisfaction. Those variables are based on social relations, which revealed the importance of connections among people and social interactions for job satisfaction development. Additionally, findings suggested that procedural justice and task-oriented leadership behavior did not affect employees' job satisfaction. These results additionally bring social interactions in the focus of job satisfaction development. A better and more in-depth understanding of these links allows management to be efficient in rapidly changing organizational circumstances to stimulate employees to work effectively. Therefore, in order to enhance employees' job satisfaction, managers need to create a working environment that is friendly, honest, and encouraging. They have to pay attention to relationships with their employees, providing them the perception of justice, respect, and trust, as well as motivation in everyday activities. Upcoming lines of research should put effort into further exploration of this cognition, by exploring some other social relations variables and their mediational impact on job satisfaction.
\end{abstract}

Keywords: job satisfaction; organizational justice; leadership behavior orientation

Academic Editor: Lucian-Ionel Cioca

Received: 24 August 2021

Accepted: 16 September 2021

Published: 23 September 2021

Publisher's Note: MDPI stays neutral with regard to jurisdictional claims in published maps and institutional affiliations.

Copyright: (C) 2021 by the authors Licensee MDPI, Basel, Switzerland. This article is an open access article distributed under the terms and conditions of the Creative Commons Attribution (CC BY) license (https:// creativecommons.org/licenses/by/ $4.0 /)$.

\section{Introduction}

Every organization aims to have satisfied employees. Satisfied employees are a valuable organizational resource for success achievement, well-being and sustainability in the long run. Many recent studies confirmed this argument. Dorta-Alfonso et al. [1] revealed the relationship between job satisfaction and individual job performance, since satisfied employees will put discretionary effort into their tasks to perform well. While some studies proposed direct relationship between job satisfaction and organizational performance (see [2]), research findings also suggested that the relationship between employee satisfaction and financial performance was mediated by some other variables, such as customer satisfaction [3,4] and organizational commitment [5], highlighting the importance of job satisfaction for organizational success in broader context.

Satisfied employees are expected to be more work committed, productive, innovative and creative, what can lead to positive organizational outcomes. They drive business results and contribute to the organizational growth and development. That is why it is crucial in today's highly competitive, unstable, and unpredictable business environment to identify factors that influence employees' job satisfaction. This paper highlights the importance of two contextual variables as potential determinants and predictors of job satisfaction, more precisely, organizational justice and leadership behavior. 
The concept of organizational justice is a term that denotes a degree of fairness by which employees perceive organizational rules, procedures, and policies that are related to their work [6]. It counts for three dimensions of justice: distributive, procedural, and interactional, which refer to the different organizational issues of just, fair, and ethical treatment. Namely, organizational justice works as an instrument to ensure whether employees are satisfied with the pattern of distribution of reward (distributive justice), processes of distribution (procedural justice), and top-down interpersonal communication (interactional justice) [7] (p. 162).

Due to empirical evidence, organizational justice has been viewed as an important factor for understanding and predicting much of organizational behavior [6], and as one of the leading factor that influences employees' job satisfaction [7]. Workers who have a high level of job satisfaction generally feel justice in their work environment and feel that their job gives them some positive features such as variety, challenge, good pay, security, autonomy, pleasant co-workers, etc. Although organizational justice has been intensively researched in relation to many organizational outcomes, its effect on job satisfaction is inadequately examined [8]. In line with this notion, this study is focused on analyzing perceived organizational justice as a predictor of job satisfaction.

It is indisputable that leaders' roles in today's business conditions have changed and that any organizational success relies on skillful leaders. Leaders' behavior and actions are instrumental towards defined objective accomplishments. An essential link in that process is satisfied employees. Influence on employees' emotions, thoughts, motivations, needs, demands, and expectations affects their job satisfaction [9]. Leaders acknowledge this influence by exhibiting a particular style or behavior, depending on the organization's situation. Generally, leadership behavior reveals the relationship between leaders and employees.

To provide a context to the research, this study accentuates two leadership behavior orientations: task-oriented and relations-oriented leadership behavior. These two types of leadership behavior are the most prominent leadership styles in current leadership literature [10]. Leaders who perform task-oriented behavior are focused on completing set tasks to achieve organizational goals. In contrast to this, leaders who adopt relationsoriented behavior are more focused on employee's welfare, encouraging collaboration, communication, building a positive relationship, and putting effort into individual support, motivation, and development [11] (p. 51).

Leaders with a different kind of behavior have the power and ability to influence an increase or decrease in job satisfaction. To achieve the optimum level of satisfaction, work environments have to be supportive, encouraging, optimistic, and stimulating. That is why leaders are anxious regarding employees' attitudes and perceptions about the organization they work for. In this context, the employee perception of justice in an organization emerged as an important and predominant factor in terms of job satisfaction [7]. In this regard, when employees feel just, fair, and ethical treatment in the organization environment, it is expected that leaders with their behaviors and activities additionally enhance their job satisfaction. Based on these considerations, this research follows the proposition of organizational justice and leadership behavior orientation as possible predictors of employee job satisfaction. Two main research question are proposed:

1. Does organizational justice predict employees' job satisfaction?

2. Does leadership behavior orientation predict employees' job satisfaction?

To address these questions in-depth and to examine the role of organizational justice and leadership behavior in predicting job satisfaction, this study focuses on three perceived organizational justice dimensions (distributive, procedural, and interactional justice) and two leadership behavior orientations (task and relations-oriented behaviors), arguing that each component will not have the same effect on job satisfaction.

Numerous studies have been conducted, relating to job satisfaction, organizational justice, and leadership style (e.g., $[6,7,12-17])$, but the research that modeled these three variables have been rare in the empirical literature. In addition, in the context of organizational sustainability, the exploration of the relationship among these variables is inevitable. Namely, 
employees' acceptance and implementation of organizational goals transfer the organization a step further. Moreover, in that stage, job satisfaction represents a crucial factor. It generates employees' creativity, innovations and better performance. Leadership enhances those outcomes. Therefore, inspiriting leadership could enhance job satisfaction and all organizational benefits arising from it. In that context, organizational justice is the base and fundamental element of organizational sustainability. Those premises should be tested in order to accomplish some knowledge from the theoretical as well as practical standpoint.

Moreover, a literature search revealed there are no similar studies in the Croatia setting. Some rare researchers considered variables such as leadership behavior, organizational justice, or job satisfaction in their research (e.g., [18-20]), but of most relevance to this research are the studies of Miloloza [21] and Jakopec et al. [22]. These studies provided empirical evidence that organizational justice and leadership behavior can be acknowledged as important antecedents of work-related outcomes in Croatian companies. Identification of this gap directed this research to leadership behavior and organizational justice as a potential predictors of job satisfaction. This research will contribute to the growing debate on job satisfaction predictors, especially in the Croatian context. Beside theoretical contribution of this paper, research results will provide practical recommendations for job satisfaction enhancement, since it is expected, as previous research results suggested, that satisfied employees impact organizational success, development, well-being and sustainability in the long run.

\section{Theoretical Framework}

\subsection{Job Satisfaction}

Job satisfaction could be defined as a pleasurable feeling, which stems from personal perceptions about fulfilments of one's job and values [23]. Abdulla et al. [24] defined job satisfaction as the degree to which people like their jobs. Job satisfaction is an emotional and effective response toward various facets of one's job [25].

Much research has been devoted to job satisfaction. Dorta-Afonso et al. [1] in their study revealed that workers' motivation and organizational commitment positively influence job satisfaction, which, in turn, enhances workers' quality of life. Moreover, they found that job satisfaction and quality of life significantly predicted individual job performance. Further, Alafeshat and Tanova [26] revealed in their study that servant leadership leads to employees satisfaction. They found that increased engagement is related to higher levels of satisfaction and retention. García-Rodríguez et al. [27] found that employees' perceptions of diversity management have a positive and significant direct effect on job satisfaction. Haider et al. [28] findings provided the support for the direct relationship between high performance work systems and job satisfaction. Sanchez-Manzanares et al. [10] examined 74 studies that have analyzed organizational factors that influence job satisfaction. Among those studies, only few researchers have found the support for the variables of leadership behavior and organizational justice as important determinants of job satisfaction, but these variables were not observed through a common research model.

Among recent research on job satisfaction, organizational justice and leadership styles, some research should be pointed out. Namely, Ngeleshi and Dominic [29] examined the effect of organizational justice and level of trust on job satisfaction. Razak and Ali [30] showed that the three components of organizational justice had significant multiple correlations with the job satisfaction and its five subscales (nature of work, supervision, coworkers, pay and promotion). Job satisfaction has a significant effect as a mediator between organizational justice, transformational leadership and organizational commitment [31]. Sunarsi et al. [31] concluded that transformational leadership has a positive and significant effect on satisfaction, both directly and indirectly through mediating job perceptions. 


\subsection{Organizational Justice and Job Satisfaction}

Organizational justice refers to employees' perception of justice and fairness in organizations. It is a level to which individuals believe that the outcomes they receive and how the organization treats them are fair, equitable, and in line with expected moral and ethical standards [32,33]. It is one of the most frequently researched areas in human resource management, organizational psychology, and organizational behavior [8] (p. 8). Research distinguishes three basic and dominant types or dimensions of organizational justice: distributive justice, procedural justice, and interactional justice $[34,35]$. Each type of justice refers to the extent to which employees perceive job-related outcomes, procedures, and interactions to be just and fair. Over the last decade, they acknowledged reliable empirical support.

Distributive justice refers to the perceived fairness of workload distribution and reward [16]. Employees experience distributive justice when they perceive that they receive an adequate return from social and economic resources [36], meaning a fair distribution of outcomes and incomes [32]. Procedural justice refers to the employee's perception of whether they have been treated fairly when interacting with their superior or other authorities in processes through which organizational outcomes are achieved [16], like decision-making processes, the human resource policies and practices that affect their work outcomes $[8,36]$. The concept of interactional justice refers to the perceived fairness about the quality of interpersonal treatment that employees receive from their authorities [36], focusing on interactions between different organizational levels [16], and suggesting that perceived fairness of interpersonal treatment with one's superior influences employee's behavior [37].

The concept of organizational justice emerges from the Adams Equity theory (1965), according to which a person perceives organizational justice based on equity and harmony assessment of inputs related to the outcomes, observing their own input-outcome ratio, and comparing it with their colleagues' ratio [38,39]. It focuses on components of each justice dimension in an exchange relationship with the organization; fairness of reward system, the fairness of decision outcomes, and the fairness of interaction between managers and subordinates. The perception of this fairness affects employees' positive or negative feelings about their treatment in the organization. In turn, employees will become motivated and satisfied if they perceive that their treatment is fair and just and vice versa.

Many research studies suggested that perceived organizational justice influences employees' attitudes and behaviors that are crucial for individual and organizational success, such as organizational commitment, job performance, turnover intention, trust, organizational citizenship behavior (e.g., [6,40,41]). Among many work-outcome variables that have been analyzed in relationship with organizational justice, job satisfaction has its significant place and share (e.g., [6,42]). Researchers mainly empirically proved the significant positive effect of each justice dimension on job satisfaction [43,44]. Cohen-Charash and Spector [34] in their meta-analysis of the role of organizational justice in the organization, highlighted findings that positive perceptions of justice and fairness are related to positive employees and organizational outcomes. Gori et al. [45] pointed out that organizational justice predicts job satisfaction from a cross-cultural perspective. Namely, it is shown that cultural settings are an important determinant of organizational justice's impact on various work outcomes [39]. Further, Alamir et al. [16] found that three organizational justice types impact organizational commitment through job satisfaction. Singhry [8] investigated organizational justice's role in the relationship between transformational leadership style and employee's job satisfaction and revealed that organizational justice has a mediating role between leadership and job satisfaction. Al-Zu'bi [13] found that all three organizational justice dimensions were positively linked with job satisfaction, suggesting that job satisfaction depends on perceived employees' organizational justice level.

Empirical evidence also supported assumptions that different organizational justice components do not affect work outcome variables the same, among which job satisfaction stands out. This standpoint is maintained through yearly research, where empirical evidence exposed that some of the justice components accounted for more variance 
on work-related outcomes, like job satisfaction, than others [6]. Namely, in most of these studies, distributive justice was a better predictor of job satisfaction and other work-related outcomes than procedural justice (e.g., [6,46]). In that vein, Elamin [6], in his study, revealed that all three components of justice play a significant role in influencing employee's job satisfaction levels, emphasizing that distributive justice tends to be a stronger predictor of job satisfaction when compared to procedural justice.

However, some findings purport that procedural justice is not a significant predictor of job satisfaction. For instance, Rahman et al. [7] revealed that distributive and interactional justice significantly affect job satisfaction, whereas procedural justice does not. Moreover, Zainalpur et al. [47], using multiple regression analysis in their study, revealed a significant impact of distributive and interactional justice on job satisfaction among middle school teachers, while procedural justice failed to show any significant relationship with job satisfaction. Additionally, in a similar vein, Bakhshi et al. [39] indicated that procedural justice was not significantly related to job satisfaction, whereas distributive justice was. Thus, when employees experience appropriate behaviors and treatment from their superiors, they feel more satisfied with their jobs. The more perception of fairness in an organization exists, the more feeling toward job satisfaction there will be [47].

In line with above reasoning, it is anticipated that interactional and distributive justice have an impact on job satisfaction. Therefore, the Hypothesis 1 is stated:

\section{Hypothesis 1 (H1). Interactional and distributive justice affect positively on job satisfaction.}

\subsection{Leadership Behavior and Job Satisfaction}

Among many factors that influence employees' job satisfaction, leadership is a significant predictor $[48,49]$. Leadership is the art of working with people. Leaders create changes. They influence, motivate, and facilitate individuals and groups to accomplish common goals [50]. Through that process that is directed toward employee's motivation for achieving settled goals and objectives, leaders influence their followers' feelings and behaviors, affecting their productivity, motivation, effectiveness, organizational commitment, as well as job satisfaction. Therefore, leaders, through their attitudes and behaviors, can force job satisfaction.

Over time, numerous leadership styles are determined, differentiating how employees are respected, treated with honesty and integrity, supplied with information, allowed to make decisions, included in open communication lines, etc. The literature abounds in various typologies of leadership styles. Beyer [51] creates a list of 50 different leadership styles found in recent literature. Each leadership style is defined and characterized by a combination of leadership behaviors [52].

Northouse [53] emphasizes that all leadership styles could be divided into two broad style approach categories differentiated by two general types of behavior orientation: task and relationship orientation behavior. Many studies empirically supported the practical existence and essential context difference among these two leadership behavior types, although their terminology may differ [54]. Namely, Bass [55] provided a systematic overview of different terms used by researchers that describe relations-oriented leadership behavior focused on the quality of the relationship with followers, and task-oriented leadership behavior focused on the task to be accomplished by followers. Relations-oriented leadership behavior is oriented on support, motivation, encouragement, trust, respect, and development of employees, while task-oriented focuses on the efficiency of goals and objectives achievements $[11,50]$. Relations-oriented leadership is an approach that puts efforts into job satisfaction, motivation, and the work-life balance of the employees [11] (p. 51). Task-oriented leadership emphasizes work procedures, activities, and goals [54], based on organizational hierarchy and interactions between managers and employees [56]. This type of behavior helps employees to be clear about what works need to be done to achieve settled goals [56], clarifying job responsibilities, work task assignments, priorities, 
deadlines, performance standards, rules, policies, procedures, etc., [50] in order to achieve effectiveness and quality [57].

Leaders' success depends on how these two leadership behavior orientations are exhibited [50]. Regardless of the terminology, many researchers throughout history have focused on analyzing the effectiveness of these behaviors in relation to work-related outcomes and have come upon findings and conclusions that supported the existence of these relations. Even long ago, back in 1962, Fleishman and Harris [58] supported the effectiveness of relations-oriented behavior, reporting that it resulted in lower employee turnover. Additionally, Patchen [59] supported task-oriented leadership behavior's effectiveness reporting its positive effects on job performance. Since then, plenty of research has confirmed their findings and supported the effectiveness of these two categories of leadership behavior regarding organizational outcomes, like employee performance and job satisfaction. Furthermore, in his detailed analysis, Bass [55] concluded that the most consistent findings are that relations-oriented behavior is positively related to the employee's job satisfaction, while evidence of the relationship between task-oriented behavior and job satisfaction has been mixed [12].

Present-day researches go in the same direction. There are many new variables alongside job satisfaction that are included in studies, and notable findings demonstrated that leadership behavior has a direct and positive impact on the overall job satisfaction of the followers (e.g., [52,60,61]). Moreover, in a recent study, Singhry [8] underlined the concept of leadership as a vital factor that ensures employee job satisfaction. Leadership behavior has a significant effect on job satisfaction, and thus leaders' adjustment to the situation improves employee's satisfaction or reduces dissatisfaction [62].

The research interest in leadership and organizational outcomes has been at its peak over the last decades. Numerous studies presented that leadership behavior, and job satisfaction shows significant relations in different sectors: from educational, private, and the public to nor for-profit sector (e.g., [17,52,63,64]). Alonderiene and Majauskaite [52] (p. 153) studied leadership styles in higher education institutions and revealed that perceived leadership styles have a significant positive relationship with job satisfaction. Considering behaviors inherent to the particular leadership style that they examined, relations-oriented behavior displayed the strongest relationship with job satisfaction, while task-oriented behavior displayed the lowest impact. To improve organizational effectiveness, Rodrigues [64] concluded that leadership style and job satisfaction predict person-organization fit within a public sector organizations. Huynh and An Hua's [57] results showed that task-oriented leadership behavior limits employees' job satisfaction in small and medium-sized enterprises. Mikkelson et al. [54] also found that task and relations-oriented leadership styles were positively related to job satisfaction, motivation, and organizational commitment as the three most crucial employee outcomes. Namely, they conclude that effective communication and relations-oriented leadership are the best predictors of satisfaction, motivation, and organizational commitment.

Based on the reasons stated above, Hypothesis 2 is stated:

Hypothesis 2 (H2). Relations-oriented leadership behavior affects positively on job satisfaction.

The research framework model is shown in Figure 1. 


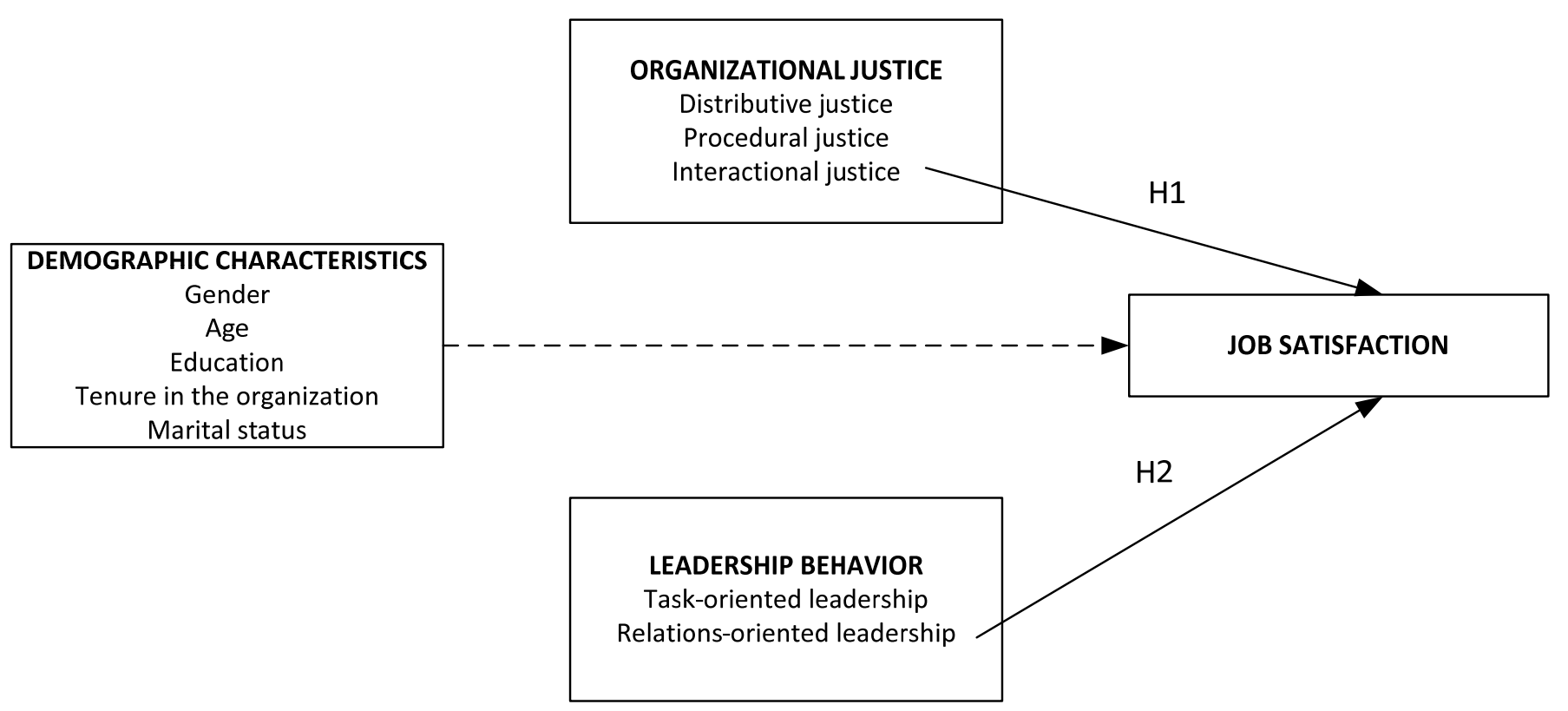

Figure 1. The research model.

\section{Methodology}

\subsection{Aim of the Research}

Job satisfaction is generally a very interesting topic from the standpoint of scientists as well as practitioners. The complexity of this phenomenon exists since it is the subject of various influences. The aim of this research was to clarify the relationship among organizational justice, leadership behavior orientation, and employees' job satisfaction, or more concretely, to find out whether organizational justice and leadership behavior predict employees' job satisfaction.

\subsection{Research Sample and Procedure}

The empirical research of this paper was conducted in Croatia during 2019 on a convenience sample. Namely, seven Croatian companies from different industries decided to participate in the research. The selected companies were from the most successful industries in Splitsko-Dalmatinska County (hospitality, retail and construction). Therefore, about 40 employees in each company completed the questionnaire. Consequently, the research sample included 298 participants. After the companies' management's approval, the participants filled out a paper-and-pencil questionnaire or an online version of the questionnaire. Distributing the questionnaires was up to a person from the HR department. The participants were aware that participation was voluntary, anonymous and that they could give up any time.

Table 1 represents sample characteristics.

The majority of respondents were men (60.2\%), those aged 28-37 (34.9\%), those with secondary education $(42.3 \%)$, those having less than 9 years of tenure $(64.5 \%)$, and those who were married $(48.7 \%)$. 
Table 1. Sample characteristics.

\begin{tabular}{|c|c|c|c|c|}
\hline \multirow{2}{*}{ Characteristic } & \multicolumn{2}{|c|}{ Respondents } & \multicolumn{2}{|c|}{ Job Satisfaction } \\
\hline & Frequency & Percentage & Mean & Range \\
\hline \multicolumn{5}{|l|}{ Gender } \\
\hline Male & 173 & 60.1 & 3.59 & $1-5$ \\
\hline Female & 115 & 39.9 & 3.91 & $2-5$ \\
\hline \multicolumn{5}{|l|}{ Age } \\
\hline $18-27$ & 84 & 28.2 & 3.21 & $1-5$ \\
\hline $28-37$ & 104 & 34.9 & 3.87 & $2-5$ \\
\hline $38-47$ & 72 & 24.2 & 4.03 & $2-5$ \\
\hline $48-57$ & 25 & 8.4 & 3.88 & $1-5$ \\
\hline $58-67$ & 13 & 4.4 & 3.75 & $2-5$ \\
\hline \multicolumn{5}{|l|}{ Education } \\
\hline Secondary education & 126 & 42.3 & 3.50 & $1-5$ \\
\hline College education & 38 & 12.8 & 3.70 & $2-5$ \\
\hline University education & 116 & 38.9 & 3.94 & $1-5$ \\
\hline Master's degree or doctoral degree & 18 & 6.0 & 3.94 & $3-5$ \\
\hline \multicolumn{5}{|l|}{ Tenure in organization } \\
\hline Less than 9 years & 191 & 64.5 & 3.60 & $1-5$ \\
\hline $10-19$ & 74 & 25.0 & 4.01 & $2-5$ \\
\hline $20-29$ & 19 & 6.4 & 3.84 & $3-5$ \\
\hline $30-39$ & 10 & 3.4 & 3.63 & $1-5$ \\
\hline 40 and more & 2 & 0.7 & 3.50 & $3-4$ \\
\hline \multicolumn{5}{|l|}{ Marital status } \\
\hline Single & 127 & 42.6 & 3.44 & $1-5$ \\
\hline Married & 145 & 48.7 & 3.96 & $2-5$ \\
\hline Divorced & 21 & 7.0 & 3.70 & $1-5$ \\
\hline Widowed & 5 & 1.7 & 4.20 & $3-5$ \\
\hline
\end{tabular}

\subsection{Research Instruments}

Organizational justice was examined by a questionnaire developed by [65]. The questionnaire was originally in Croatian. Through this questionnaire, three types of organizational justice were explored; distributive, procedural, and interactional justice. It included 15 items, five items per each type of justice. For example, "The organization rewards me fairly given the stress and complexity of my job" or "I get clear feedback on the quality of my work" or "My organization makes it clear to me that I am a valuable employee." A 5-point Likert scale was used for participants' answers, where: 1 means strongly disagree, 2 means disagree, 3 means neither agree nor disagree, 4 means agree, 5 means strongly agree. The total score of each type of organizational justice was calculated as the average value of participants' answers on 5 items related to that type of justice. Cronbach's Alpha demonstrated high reliability of questionnaire for each type of justice, distributive justice $(\alpha=0.949)$, procedural justice $(\alpha=0.915)$, interactional justice $(\alpha=0.925)$.

The data on leadership behavior orientation was collected by an adopted questionnaire originally named Leadership Behavior Questionnaire and developed by [53]. Šehić and Pebava [66] have translated this questionnaire into Croatian. This questionnaire consists of 20 items suggesting the leader's behavior is task or relations oriented. For example, "My supervisor by himself develops an action plan" or "My supervisor accepts the suggestions of his subordinates". A 5-point Likert scale was used for participants' answers, where: 1 means never, 2 means seldom, 3 means occasionally, 4 means often, and 5 means always. The total score of each leadership orientation was calculated as the average value of participants' answers on 10 items related to each leadership orientation. Cronbach's alpha showed the acceptable reliability of the questionnaire for each leadership behavior orientation; relations-oriented leadership $(\alpha=0.919)$ or task-oriented leadership $(\alpha=0.929)$. 
Job satisfaction was explored by one question. Namely, job satisfaction was considered as a global feeling about the job. This global approach is applied when the overall attitude is one of interest [46]. Therefore, the participants were asked to examine their overall job satisfaction on a 5-point Likert scale where: 1 means very dissatisfied, 2 means dissatisfied, 3 means neither satisfied nor dissatisfied, 4 means satisfied, and 5 means very satisfied.

Additionally, the data on employee's demographic characteristics (gender, age, education, tenure in organization, and marital status) was also collected. Variable gender was coded as dummy variable ( $1=$ male, $2=$ female). Age and tenure were treated as continuous variable. Education was treated as categorical variable and measured with four item scale (from secondary education to doctoral education). Marital status was also treated as a categorical variable (single, married, divorced, widowed). That can all be seen in Table 1.

\subsection{Common Method Variance}

Considering the fact that all data are self-reported and are collected through the same questionnaire during the same period of time, following Podsakoff et al. [58], for investigation of the questionnaire items, Harman's single factor test was conducted. The first factor represents $40.54 \%$ of the variance, which suggested that CMV was not problematic and did not cause any problems within the data analysis.

\subsection{Data Analysis}

Data analysis was conducted using SPSS 23 (Statistical Package for Social Sciences). Statistical procedures applied in this research are Cronbach's alpha, descriptive statistics, correlation analysis, and hierarchical regression analysis.

\section{Research Results}

Introductory analyses were directed towards descriptive statistics. These results are presented in Table 2.

Table 2. Descriptive statistics.

\begin{tabular}{ccccccccc}
\hline \multicolumn{2}{c}{ Variables } & Mean & Median & Mode & Std. Dev. & Min & Max & N \\
\hline \multicolumn{2}{c}{ Job satisfaction } & 3.71 & 4.00 & 4.00 & 0.816 & 1.00 & 5.00 & 297 \\
\hline \multirow{2}{*}{$\begin{array}{c}\text { Organizational } \\
\text { justice }\end{array}$} & Distributive & 3.31 & 3.60 & 4.00 & 0.931 & 1.00 & 5.00 & 298 \\
& Procedural & 3.50 & 3.60 & 4.00 & 0.848 & 1.00 & 5.00 & 298 \\
$\begin{array}{c}\text { Leadership behavior } \\
\text { orientation }\end{array}$ & Interactional & 3.57 & 3.80 & 4.00 & 0.854 & 1.00 & 5.00 & 298 \\
\hline
\end{tabular}

The descriptive statistics showed that the mean value of respondents' job satisfaction was 3.71 suggesting that respondents were satisfied with their jobs. The value of the median and the mode implied the same assertion. Regarding organizational justice, the mean value of distributive justice was the lowest $(\mathrm{M}=3.31)$, the mean value of procedural justice was 3.50, while the mean value of interactional justice was the highest $(M=3.57)$. Since the level of distributive justice was closed 3, it implied that respondents neither agreed nor disagreed that the resources were justly allocated. Additionally, since the level of procedural and interactional justice tended toward 4 , it could be stated that respondents agreed that there was fairness and transparency of the processes by which decisions are made (procedural justice). They also agreed that in their organization, they were treated with dignity and respect (interactional justice). Concerning leadership behavior orientation, the results of descriptive statistics suggested that leaders were more often oriented toward tasks than toward relations. Namely, the mean value of task-oriented leadership is 3.80 , while the mean value of relations-oriented leadership is 3.66. Thus, leaders focused more 
on achieving set tasks and objectives than on their employees' support and motivation.

Table 3 presents correlations among researched variables.

Table 3. Correlation coefficients.

\begin{tabular}{|c|c|c|c|c|c|c|c|c|c|c|c|c|}
\hline & & 1 & 2 & 3 & 4 & 5 & 6 & 7 & 8 & 9 & 10 & 11 \\
\hline 1. & Job satisfaction & 1 & & & & & & & & & & \\
\hline 2. & Gender & $0.198 * *$ & 1 & & & & & & & & & \\
\hline 3. & Age & $0.263 * *$ & 0.032 & 1 & & & & & & & & \\
\hline 4. & Education & $0.251 * *$ & $0.328 * *$ & 0.082 & 1 & & & & & & & \\
\hline 5. & Marital status & $0.239 * *$ & 0.089 & $0.531^{* *}$ & $0.166^{* *}$ & 1 & & & & & & \\
\hline 6. & $\begin{array}{l}\text { Tenure } \\
\text { in the organization }\end{array}$ & 0.101 & 0.026 & $0.722 * *$ & 0.009 & $0.478^{* *}$ & 1 & & & & & \\
\hline 7. & Distributive justice & $0.727 * *$ & 0.101 & $0.286^{* *}$ & $0.178^{* *}$ & $0.253^{* *}$ & $0.151^{* *}$ & 1 & & & & \\
\hline 8. & Procedural justice & $0.681 * *$ & $0.129 *$ & $0.230 * *$ & $0.244^{* *}$ & $0.230^{* *}$ & $0.130 *$ & $0.770 * *$ & 1 & & & \\
\hline 9. & Interactional justice & $0.720 * *$ & $130 *$ & $0.206^{* *}$ & $0.220 * *$ & $0.220 * *$ & $0.135 *$ & $0.787^{* *}$ & $0.847 * *$ & 1 & & \\
\hline 10. & $\begin{array}{l}\text { Task-oriented } \\
\text { leadership }\end{array}$ & $0.582 * *$ & 0.061 & $0.181^{* *}$ & $0.196^{* *}$ & $0.173 * *$ & 0.072 & $0.608^{* *}$ & $0.675^{* *}$ & $0.704^{* *}$ & 1 & \\
\hline 11. & $\begin{array}{l}\text { Relations-oriented } \\
\text { leadership }\end{array}$ & $0.638^{* *}$ & 0.069 & $0.207^{* *}$ & $0.170^{* *}$ & $0.145 *$ & 0.101 & 0.653 ** & $0.666^{* *}$ & $0.721 * *$ & $0.869 * *$ & 1 \\
\hline
\end{tabular}

${ }^{* *}$ Correlation is significant at the 0.01 level (2-tailed). ${ }^{*}$ Correlation is significant at the 0.05 level (2-tailed).

Job satisfaction was related to all employee demographic characteristics except tenure in the organization. Those correlations were correlations of weak intensity. Furthermore, job satisfaction was strongly related to all types of organizational justice and moderately related to leadership behavior orientations.

To answer the research questions of this paper or to assess the ability of organizational justice and leadership behavior orientation to predict the level of job satisfaction, after controlling for the influence of demographic variables, hierarchical regression analysis has been conducted in three steps. Control variables, which included employees' demographic characteristics (gender, age, education, marital status, and tenure in the organization), were entered in Step 1, types of organizational justice (distributive, procedural, and interactional) were entered in Step 2, while two possible leadership behavior orientations (task-oriented leadership and relations-oriented leadership) were entered in Step 3. The results of hierarchical regression analysis are presented in Table 4. 
Table 4. Hierarchical regression analysis.

\begin{tabular}{|c|c|c|c|c|c|c|c|c|c|}
\hline & \multirow{2}{*}{ Predictor } & & \multirow{2}{*}{$\beta$} & \multirow{2}{*}{$\mathbf{R}$} & \multirow{2}{*}{$\mathrm{R}^{2}$} & \multirow{2}{*}{$\Delta \mathbf{R}$} & \multirow{2}{*}{$\mathbf{F}$} & \multicolumn{2}{|c|}{ Collinearity Statistics } \\
\hline & & & & & & & & Tolerance & VIF \\
\hline \multirow{5}{*}{ 1. Step } & \multirow{5}{*}{ Demographic variables } & Gender & $0.126^{*}$ & \multirow{5}{*}{0.409} & \multirow{5}{*}{0.168} & \multirow{5}{*}{0.168} & \multirow{5}{*}{$11.235^{* * *}$} & 0.893 & 1.120 \\
\hline & & Age & $0.330^{* * *}$ & & & & & 0.449 & 2.225 \\
\hline & & Education & $0.165^{* *}$ & & & & & 0.873 & 1.146 \\
\hline & & Marital status & 0.125 & & & & & 0.675 & 1.482 \\
\hline & & Tenure in the organization & $-0.184^{*}$ & & & & & 0.473 & 2.114 \\
\hline \multirow{7}{*}{ 2. Step } & \multirow{4}{*}{ Demographic variables } & Gender & $0.092 *$ & & & & & 0.890 & 1.123 \\
\hline & & Education & 0.038 & & & & & 0.831 & 1.204 \\
\hline & & Marital status & 0.039 & & & & & 0.666 & 1.501 \\
\hline & & Tenure in the organization & $-0.156^{* *}$ & & & & & 0.466 & 2.147 \\
\hline & \multirow{3}{*}{ Organizational justice } & Distributive justice & $0.327^{* * *}$ & \multirow{3}{*}{0.786} & \multirow{3}{*}{0.617} & \multirow{3}{*}{0.450} & \multirow{3}{*}{$108.184^{* * *}$} & 0.308 & 3.249 \\
\hline & & Procedural justice & 0.076 & & & & & 0.244 & 4.096 \\
\hline & & Interactional justice & $0.370^{* * *}$ & & & & & 0.233 & 4.293 \\
\hline \multirow{9}{*}{ 3. Step } & \multirow{4}{*}{ Demographic variables } & Gender & $0.092 *$ & & & & & 0.887 & 1.127 \\
\hline & & Age & $0.120 *$ & & & & & 0.420 & 2.378 \\
\hline & & Marital status & 0.067 & & & & & 0.647 & 1.546 \\
\hline & & Tenure in the organization & $-0.163^{* *}$ & & & & & 0.460 & 2.173 \\
\hline & \multirow{3}{*}{ Organizational justice } & Distributive justice & $0.277^{* * *}$ & & & & & 0.296 & 3.385 \\
\hline & & Procedural justice & 0.069 & & & & & 0.234 & 4.268 \\
\hline & & Interactional justice & $0.304^{* * *}$ & & & & & 0.211 & 4.734 \\
\hline & \multirow{2}{*}{ Leadership behavior orientation } & Task-oriented leadership & -0.144 & \multirow{2}{*}{0.798} & \multirow{2}{*}{0.637} & \multirow{2}{*}{0.019} & \multirow{2}{*}{$7.343^{* * *}$} & 0.208 & 4.811 \\
\hline & & Relations-oriented leadership & $0.295^{* * *}$ & & & & & 0.195 & 5.128 \\
\hline
\end{tabular}


Variables entered into Step 1 (demographic characteristics) explained $16.8 \%$ of the variance in job satisfaction, $\mathrm{F}(5,279)=11.235, p \leq 0.001$. Organizational justice that was introduced into Step 2 explained an additional and significant $45 \%$ of the variance in job satisfaction, $\mathrm{F}(3,276)=108.184, p \leq 0.001$. Adding leadership behavior orientation to the regression model at Step 3 explained additional and significant $1.9 \%$ of the variance in job satisfaction, $\mathrm{F}(2,274)=7.343, p \leq 0.001$. When all variables were included in step 3 of the regression model, it was evident that the most important predictors of job satisfaction were interactional justice, relations-oriented leadership, and distributive justice. Among demographic variables, predictors of job satisfaction were gender, age, and tenure in the organization. Together, all observed variables accounted for $63.7 \%$ of the variance in job satisfaction, $\mathrm{F}(10,274)=48.063, p \leq 0.001$.

\section{Discussion, Implications and Conclusions}

\subsection{Discussion}

This study attempted to clarify the effect of three types of organizational justice and two different leadership behavior orientations on employees' job satisfaction. Hierarchical regression analysis was conducted to examine the influence of organizational justice that could be considered as an ultimate precondition with the priority in job satisfaction determination; and leadership behavior orientation that represents an additionally important factor of employees' job satisfaction. According to this consideration, organizational justice is entered into the model before leadership behavior orientation. Namely, in the conceptualization of the research, it is considered that the requirement for job satisfaction development is the existence of organizational justice. Only when organizational justice exists, then leaders by their activities and styles could additionally enhance employees' job satisfaction.

Research results showed that interactional and distributive justice effected job satisfaction, which is in line with some previous research $[7,47]$, while procedural justice was not a job satisfaction predictor, which is also confirmed by earlier research [6,7,39]. Moreover, interactional justice had the strongest impact on job satisfaction, which has also been uncovered by $[67,68]$. Therefore, the results of this paper suggested that employees' job satisfaction was strongly affected by the fairness of interpersonal treatment that they have received from their managers. In addition, in job satisfaction generation, the employees were very sensitive to the fairness of workload distribution and rewards. On the other side, the fairness and the transparency of the processes by which decisions were made, did not effected employees' job satisfaction. This is in line with previous research that suggested that distributive justice is a more important predictor of individual outcomes such as job satisfaction, while procedural justice is more related to organizational outcomes [6]. Therefore, organizations that nurture fair and justice distribution of outcomes and incomes and fair superior treatment add value to their work environment, influencing employee satisfaction. It might be that employees do not consider the fairness of organizations procedures to be much relevant for their outcomes, as long as they perceive the fairness of workload distribution, reward and as long as they have good relations with their superiors.

These results should be complemented by the results regarding leadership behavior orientation. Namely, research results showed that relations-related leadership behavior predicted job satisfaction, which was also confirmed by some past research [52,54,55], while task-oriented leadership was not a job satisfaction predictor. This result was in line with the above-presented results on organizational justice. Namely, interactional justice, which is related to the fairness of interpersonal treatment, was the strongest determinant of job satisfaction. Concurrently, relations-related leadership behavior had an almost equally powerful impact on job satisfaction. Both variables are based on social relations that reveal the importance of the connections among people and social interactions for job satisfaction development. Thus, the findings indicated that when employees have a positive perception of interactional justice in their organizations, leaders can have a more decisive influence on their job satisfaction, exhibiting relations-oriented leadership behavior. 


\subsection{Theoretical Contributions}

The first contribution of this paper is the cognition about the importance of social relations for job satisfaction development. Secondly, this paper contributes to a new knowledge regarding how employee satisfaction can be improved, which could have implications on performance enhancement. This is of high importance in today's globalized world, because satisfied employees are a valuable organizational asset that can increase business success and improve, develop and maintain organizational sustainability.

Thirdly, this paper fills the void of scarce research done in the domain of job satisfaction predictors, especially in Croatian context.

\subsection{Managerial Implications}

The present study results bring social interactions in the focus of job satisfaction development, suggesting that a better and more in-depth understanding of link among leadership orientation, organizational justice and job satisfaction allows management to be efficient in rapidly changing organizational circumstances to stimulate employees to work effectively. According to results, in order to enhance employees' job satisfaction, managers need to create a working environment that is friendly, honest, and encouraging. Additionally, in their everyday activities they should adopt this cognition to promote inspiring social interactions. They should put an effort on developing supportive and encouraging work environment. Finally, managers need to pay attention to relationships with their employees, providing them the perception of justice, respect, and trust, as well as motivation in everyday activities. Consequently, all these activities will help managers to develop and maintain positive and encouraging working environment that will enable employees to feel satisfied at their job.

\subsection{Conclusions, Limitation and Future Lines of Research}

The present study explored whether organizational justice and leadership behavior orientation predict job satisfaction. Croatia was the polygon for the empirical research. Research results showed that interactional justice, distributive justice and relations-related leadership are job satisfaction predictors. Those variables are based on social relations, which revealed the importance of the connections among people and social interactions for job satisfaction development.

The conclusions of this study should be observed with some reservations related to the research limitations that are as follows. This was the cross-sectional analysis, which does not provide findings over a longer period. Therefore, for some future research, a longitudinal study could be more appropriate. Research sample also has some limitations, and future research should enhance research sample and consider to include some other industries in the analysis. Among limitations are also self-reported measures. Therefore, in order to avoid subjectivisms of responses, future research could consider some objective alternative sources of information. Additionally, further research could include other factors that could explain the remaining variance of job satisfaction, such as job characteristics, rewards, and other contextual variables that could be the antecedents of job satisfaction. Besides, some other work attitudes such as organizational commitment or organizational citizenship behavior could be explored, which could provide comparisons of predictors of different work attitudes. In addition, future research could expand this work focusing on the mediator and moderator variables of analyzed relationships such as employee traits, motivation or delegation.

Author Contributions: Conceptualization, D.B. and I.B.; methodology, I.B.; software, D.B.; validation, D.B. and I.B.; formal analysis, D.B.; investigation, I.B.; resources, D.B.; data curation, I.B.; writingoriginal draft preparation, D.B. and I.B.; writing-review and editing, D.B. and I.B.; visualization, D.B.; supervision, I.B.; project administration, I.B.; funding acquisition, D.B. Both authors have read and agreed to the published version of the manuscript.

Funding: This research received no external funding. 
Institutional Review Board Statement: Not applicable.

Informed Consent Statement: Not applicable.

Data Availability Statement: Not applicable.

Conflicts of Interest: The authors declared no potential conflicts of interest with respect to the research, authorship, or publication of this article.

\section{References}

1. Dorta-Afonso, D.; González-De-La-Rosa, M.; García-Rodríguez, F.; Romero-Domínguez, L. Effects of High-Performance Work Systems (HPWS) on Hospitality Employees' Outcomes through Their Organizational Commitment, Motivation, and Job Satisfaction. Sustainability 2021, 13, 3226. [CrossRef]

2. Altamimi, A.N.A. Literature on The Relationships between Organizational Performance and Employee Job Satisfaction. Arch. Bus. Res. 2019, 7. [CrossRef]

3. Chi, C.G.; Gursoy, D. Employee satisfaction, customer satisfaction, and financial performance: An empirical examination. Int. J. Hosp. Manag. 2009, 28, 245-253. [CrossRef]

4. Banker, R.D.; Konstans, C.; Mashruwala, R. A Contextual Study of Links between Employee Satisfaction, Employee Turnover, Customer Satisfaction and Financial Performance; The University of Texas at Dallas: Dallas, TX, USA, 2000.

5. Ahmad, M.R.; Raja, R. Employee Job Satisfaction and Business Performance: The Mediating Role of Organizational Commitment. Vision J. Bus. Perspect. 2021, 25, 168-179. [CrossRef]

6. Elamin, A.M. Perceived organizational justice and work-related attitudes: A study of Saudi employees. World J. Entrep. Manag. Sustain. Dev. 2012, 8, 71-88. [CrossRef]

7. Rahman, M.; Haque, M.; Elahi, F.; Miah, W. Impact of Organizational Justice on Employee Job Satisfaction: An Empirical Investigation. Am. J. Bus. Manag. 2015, 4, 162-171. [CrossRef]

8. Singhry, H.B. Perceptions of leader transformational justice and job satisfaction in public organizations. Int. J. Public Leadersh. 2018, 14, 80-95. [CrossRef]

9. Chiva, R.; Alegre, J. Emotional intelligence and job satisfaction: The role of organizational learning capability. Pers. Rev. 2008, 37, 680-701. [CrossRef]

10. Sanchez-Manzanares, M.; Rico, R.; Antino, M.; Uitdewilligen, S. The Joint Effects of Leadership Style and Magnitude of the Disruption on Team Adaptation: A Longitudinal Experiment. Group Organ. Manag. 2020, 45, 836-864. [CrossRef]

11. Ruzgar, N. The Effect of Leaders' Adoption of Task-Oriented or Relationship-Oriented Leadership Style on Leader-Member Exchange (LMX), In the Organizations That Are Active in Service Sector: A Research on Tourism Agencies. J. Bus. Adm. Res. 2018, 7, 50. [CrossRef]

12. Fernández, S. Examining the Effects of Leadership Behavior on Employee Perceptions of Performance and Job Satisfaction. Public Perform. Manag. Rev. 2008, 32, 175-205. [CrossRef]

13. Al-Zu'Bi, H.A. A Study of Relationship between Organizational Justice and Job Satisfaction. Int. J. Bus. Manag. 2010, 5, p102. [CrossRef]

14. Liao-Holbrook, F. Integrating Leader Fairness and Leader-Member Exchange in Predicting Work Engagement: A Contingency Approach. Master's Thesis, Portland State University, Portland, OR, USA, 2013. [CrossRef]

15. Nwokolo, E.; Ifeanacho, N.; Anazodo, N.N. Perceived Organizational Justice and Leadership styles as Predictors of Employee Engagement in the Organization. Nile J. Bus. Econ. 2017, 2, 16. [CrossRef]

16. Alamir, I.; Ayoubi, R.; Massoud, H.; Al Hallak, L. Transformational leadership, organizational justice and organizational outcomes. Leadersh. Organ. Dev. J. 2019, 40, 749-763. [CrossRef]

17. Mwesigwa, R.; Tusiime, I.; Ssekiziyivu, B. Leadership styles, job satisfaction and organizational commitment among academic staff in public universities. J. Manag. Dev. 2020, 39, 253-268. [CrossRef]

18. Bakotić, D. Relationship between job satisfaction and organisational performance. Econ. Res.-Ekon. Istraž. 2016, 29, 118-130. [CrossRef]

19. Udovčić, A.; Požega, Ž.; Crnković, B. Analysis of leadership styles in Croatia. Ekon. Vjesn. Rev. Contemp. Entrep. Bus. Econ. Issues 2014, XXVII, 71-80.

20. Miloloza, I. Analysis of the Leadership Style in Relation to the Characteristics of Croatian Enterprises. Interdiscip. Descr. Complex Syst. 2018, 16, 249-264. [CrossRef]

21. Jakopec, A.; Sušanj, Z.; Stamenković, S. Uloga stila rukovođenja i organizacijske pravednosti u identifikaciji zaposlenika s organizacijom. Suvrem. Psihol. 2013, 16, 185-201.

22. Pomper, I.; Malbašić, I. Utjecaj transformacijskog vodstva na zadovoljstvo zaposlenika poslom i njihovu odanost organizaciji. Ekon. Pregl. 2016, 67, 135-152.

23. Raymond, A.; Hollenbeck, J.R.; Gerhart, B.A.R.R.Y.; Wright, P.M. Human Resource Management—Gaining a Competitive AdvantageInternational Edition, 5th ed.; McGraw-Hill College: New York, NY, USA, 2006.

24. Abdulla, J.; Djebarni, R.; Mellahi, K. Determinants of job satisfaction in the UAE: A case study of the Dubai police. Pers. Rev. 2011, 40, 126-146. [CrossRef] 
25. Maamari, B. Changing management history, gender moderating pay to job satisfaction for IS users. J. Manag. Hist. 2014, 20, 311-332. [CrossRef]

26. Alafeshat, R.; Tanova, C. Servant Leadership Style and High-Performance Work System Practices: Pathway to a Sustainable Jordanian Airline Industry. Sustainability 2019, 11, 6191. [CrossRef]

27. García-Rodríguez, F.J.; Dorta-Afonso, D.; González-De-La-Rosa, M. Hospitality diversity management and job satisfaction: The mediating role of organizational commitment across individual differences. Int. J. Hosp. Manag. 2020, 91, 102698. [CrossRef]

28. Haider, S.; De-Pablos-Heredero, C.; De-Pablos-Heredero, M. A Three-Wave Longitudinal Study of Moderated Mediation between High-Performance Work Systems and Employee Job Satisfaction: The Role of Relational Coordination and Peer Justice Climate. Front. Psychol. 2020, 11, 792. [CrossRef]

29. Ngeleshi, J.; Dominic, T. Organizational Justice and Job Satisfaction among Different Employee Groups: The Mediating Role of Trust. Bus. Manag. Rev. 2021, 23, 71-88.

30. Abd Razak, M.R.; Ali, E. Effect of Organizational Justice on Job Satisfaction in the Service Sector in Malaysia. Manag. Res. J. 2021, 10, 77-86. [CrossRef]

31. Silitonga, N.; Novitasari, D.; Sutardi, D.; Sopa, A.; Asbari, M.; Yulia, Y.; Supono, J.; Fauji, A. The relationship oftransformational leadership, organizational justice and organizational commitment: A mediation effect of job satisfaction. J. Crit. Rev. 2020, 7, 89-108.

32. Fuchs, S. The impact of manager and top management identification on the relationship between perceived organizational justice and change-oriented behavior. Leadersh. Organ. Dev. J. 2011, 32, 555-583. [CrossRef]

33. Gibson, C.; Gallan, B.; Warren, A. Engaging creative communities in an industrial city setting: A question of enclosure. Gateways Int. J. Community Res. Engag. 2012, 5, 1-15. [CrossRef]

34. Cohen-Charash, Y.; Spector, P.E. The role of justice in organizations: A meta-analysis. Organ. Behav. Hum. Decis. Process. 2001, 86, 278-321. [CrossRef]

35. Folger, R.; Cropanzano, R. Fairness theory: Justice as accountability. Adv. Organ. Justice 2001, 1, 12.

36. Fujimoto, Y.; Härtel, C.; Azmat, F. Towards a diversity justice management model: Integrating organizational justice and diversity management. Soc. Responsib. J. 2013, 9, 148-166. [CrossRef]

37. Greenberg, J. Organizational justice: The dynamics of fairness in the workplace. In APA Handbook of Industrial and Organizational Psychology; Maintaining, Expanding, and Contracting the Organization; Zedeck, S., Ed.; American Psychological Association: Washington, DC, USA, 2001; Volume 3, pp. 271-327. [CrossRef]

38. Amazue, L.O.; Nwatu, O.H.; Ome, B.N. Relationship between Perceived Leadership Style, Organizational Justice and Work Alienation among Nigerian University Employees. IOSR J. Bus. Manag. 2016, 18, 76-85. [CrossRef]

39. Bakhshi, A.; Kumar, A.; Kumari, A. National Culture and Organizational Citizenship Behavior: Development of a Scale; Global Publishing House: Tamil Nadu, India, 2009.

40. Judge, T.A.; Colquitt, J.A. Organizational Justice and Stress: The Mediating Role of Work-Family Conflict. J. Appl. Psychol. 2004, 89, 395-404. [CrossRef]

41. Mylona, E.; Mihail, D. Enhancing Employees' Work Performance through Organizational Justice in the Context of Financial Crisis. A Study of the Greek Public Sector. Int. J. Public Adm. 2018, 42, 509-519. [CrossRef]

42. Strom, D.L.; Sears, K.L.; Kelly, K.M. Work Engagement: The Roles of Organizational Justice and Leadership Style in Predicting Engagement among Employees. J. Leadersh. Organ. Stud. 2014, 21, 71-82. [CrossRef]

43. Totawar, A.K.; Nambudiri, R.; Selvaraj, P. Justice, Satisfaction, Commitment: Mediation of Quality of Work Life and Psychological Capital. Acad. Manag. Proc. 2013, 2013, 15432. [CrossRef]

44. Sembiring, N.; Nimran, U.; Astuti, E.S.; Utami, H.N. The effects of emotional intelligence and organizational justice on job satisfaction, caring climate, and criminal investigation officers' performance. Int. J. Organ. Anal. 2020, 28, 1113-1130. [CrossRef]

45. Gori, A.; Topino, E.; Palazzeschi, L.; Di Fabio, A. How Can Organizational Justice Contribute to Job Satisfaction? A Chained Mediation Mode. Sustainability 2020, 12, 7902. [CrossRef]

46. Lee, H.-R. An Empirical Study of Organizational Justice as a Mediator in the Relationships among Leader-Member Exchange and Job Satisfaction, Organizational Commitment, and Turnover Intentions in the Lodging Industry. April 2000. Available online: https:/ /vtechworks.lib.vt.edu/handle/10919/27465 (accessed on 23 August 2021).

47. Zainalipour, H.; Fini, A.A.S.; Mirkamali, S.M. A study of relationship between organizational justice and job satisfaction among teachers in Bandar Abbas middle school. Procedia-Soc. Behav. Sci. 2010, 5, 1986-1990. [CrossRef]

48. Mosadeghrad, A.M.; Yarmohammadian, M.H. A study of relationship between managers' leadership style and employees' job satisfaction. Leadersh. Health Serv. 2006, 19, 11-28. [CrossRef]

49. Saleem, H. The Impact of Leadership Styles on Job Satisfaction and Mediating Role of Perceived Organizational Politics. Procedia-Soc. Behav. Sci. 2015, 172, 563-569. [CrossRef]

50. Yukl, G. Effective Leadership Behavior: What We Know and What Questions Need More Attention. Acad. Manag. Perspect. 2012, 26, 66-85. [CrossRef]

51. Beyer, B. Blending Constructs and Concepts: Development of Emerging Theories of Organizational Leadership and Their Relationship to Leadership Practices for Social Justice. Int. J. Educ. Leadersh. Prep. 2012, 7, n3. Available online: https: / / eric.ed.gov/?id=EJ997470 (accessed on 23 August 2021). 
52. Alonderiene, R.; Majauskaite, M. Leadership style and job satisfaction in higher education institutions. Int. J. Educ. Manag. 2016, 30, 140-164. [CrossRef]

53. Northouse, P.G. Leadership: Theory and Practice, 6th ed.; SAGE Publications, Inc.: Thousand Oaks, CA, USA, 2012.

54. Mikkelson, A.C.; York, J.A.; Arritola, J. Communication Competence, Leadership Behaviors, and Employee Outcomes in Supervisor-Employee Relationships. Bus. Prof. Commun. Q. 2015, 78, 336-354. [CrossRef]

55. Bass, B.M. Bass E Stogdill's Handbook of Leadership: Theory, Research E Managerial Applications, Subsequent ed.; Free Press: New York, NY, USA; London, UK, 1990.

56. McMurray, A.; Pirola-Merlo, A.; Sarros, J.C.; Islam, M.M.; Islam, M. Leadership, climate, psychological capital, commitment, and wellbeing in a non-profit organization. Leadersh. Organ. Dev. J. 2010, 31, 436-457. [CrossRef]

57. Huynh, T.N.; Hua, N.T.A. The relationship between task-oriented leadership style, psychological capital, job satisfaction and organizational commitment: Evidence from Vietnamese small and medium-sized enterprises. J. Adv. Manag. Res. 2020, 17, 583-604. [CrossRef]

58. Fleishman, E.A.; Harris, E.F. Patterns of leadership behavior related to employee grievances and turnover. Pers. Psychol. 1962, 15, 43-56. [CrossRef]

59. Patchen, M. Supervisory Methods and Group Performance Norms. Adm. Sci. Q. 1962, 7, 275. [CrossRef]

60. Rafferty, A.; Griffin, M. Dimensions of transformational leadership: Conceptual and empirical extensions. Leadersh. Q. 2004, 15, 329-354. [CrossRef]

61. Chang, S.; Lee, M. A study on relationship among leadership, organizational culture, the operation of learning organization and employees' job satisfaction. Learn. Organ. 2007, 14, 155-185. [CrossRef]

62. Al-Sada, M.; Al-Esmael, B.; Faisal, M.N. Influence of organizational culture and leadership style on employee satisfaction, commitment and motivation in the educational sector in Qatar. EuroMed J. Bus. 2017, 12, 163-188. [CrossRef]

63. Rothfelder, K.; Ottenbacher, M.C.; Harrington, R.J. The impact of transformational, transactional and non-leadership styles on employee job satisfaction in the German hospitality industry. Tour. Hosp. Res. 2012, 12, 201-214. [CrossRef]

64. Rodriguez, C. An Examination of the Correlation between Leadership Style and Job Satisfaction for Predicting PersonOrganization Fit in Public Sector Organizations. Ph.D. Thesis, Grand Canyon University, Phoenix, AZ, USA, 2020.

65. Jakopec, A.; Sušanj, Z. Provjera dimenzionalnosti konstrukta pravednosti u organizacijskom kontekstu. Psihol. Teme 2014, 23, 305-325.

66. Šehić, D.; Penava, S. Leadership; Univerzitet u Sarajevu, Ekonomski Fakultet: Sarajevo, Bosnia and Herzegovina, 2007.

67. Pettijohn, C.E.; Pettijohn, L.S.; D'Amico, M. Characteristics of performance appraisals and their impact on sales force satisfaction. Hum. Resour. Dev. Q. 2001, 12, 127-146. [CrossRef]

68. Ismail, A.; Zakaria, N. Relationship between Interactional Justice and Pay for Performance as an Antecedent of Job Satisfaction: An Empirical Study in Malaysia. Int. J. Bus. Manag. 2009, 4, 190. [CrossRef] 